\title{
Patriarchal Hierarchies of Power and the Subordination of Women: Real Doll as a Replacement of Woman Figure
}

\author{
Natasha Shokri (Corresponding Author) \\ UNESCO Youth Peace Ambassador, \\ The United Nation University of UPEACE, Costa Rica \\ E-mail: Natasha.shokri@gmail.com \\ Moussa Pourya Asl \\ School of Humanities, Universiti Sains Malaysia \\ 11800 USM, Pulau Pinang. Penang, Malaysia \\ E-mail: Ms_pourya@yahoo.com
}

Doi:10.7575/aiac.alls.v.6n.4p.216

URL: http://dx.doi.org/10.7575/aiac.alls.v.6n.4p.216
Received: $15 / 04 / 2015$

Accepted: 28/06/2015

\begin{abstract}
The social structure of the family has always been in the state of transformation. In the past centuries, the nuclear family was replaced with a Patriarchal Family which lasted for only two centuries from 16th to the beginning of 18 th century. In this new structure of the family, men were privileged to play the role of the master and the women were marginalized and subordinated. Recent years, however, has witnessed a re-adjustment of this order towards a more equal distribution of power relations. These changes in family structure has ever since initiated new conflicts leading to establishment of the physical and psychological bonds between men and dolls. The present study aims to find out the major sociopsychological reasons behind this conflict. In a qualitative library based study, the researchers attempt to analyse the video interview of some of the doll-owners. In the survey conducted in this study, the video of "Guys and Dolls", BBC Video Documentary, has been shown to 10 participants, five male and five female. Then, a questionnaire was distributed to ask for their opinion based on their gender. The findings of this analysis reveal that women can hardly accept the notion of using dolls as replacement to real partners in comparison with men. On the contrary, the male participants advocated the employment of dolls as sexual replacement for the real woman figure.
\end{abstract}

Keywords: Patriarchy, Real Doll, Oedipus complex, Female Subordination, Family

\section{Introduction}

The social structure of the family has always been in the state of transformation. These changes in turn have led to alterations in the hierarchies of power at work in the deep structure of the communities. Men desire to obtain social power, their being privileged is undeniable. This is due to the fact that men need to have power in order to boost their self-esteem. Nonetheless, as power asymmetry has been changed during recent decades, remarkably with the first and the second wave of feminism, women have consequently achieved more responsibilities, both economically and politically, in society. Numerous changes in power relations has also inevitably initiated the conflict of "Guys and Dolls".

These Real Dolls are life-size sex dolls produced by Abyss Creations in San Marcos, California. They are made of PVC skeleton with steel joints and silicone flesh, which was tried to replace the real feeling of human bodies` stimulation. The customers of these real dolls are nearly from every country in the world, but the United State, Germany, Australia and The United Kingdom are the largest international markets. Now 4000 real dolls are living with their guy's owner. Each doll costs around 4,000 pounds and for those guys who love the companionship of real dolls more than that of women, it worth every penny. But what these dolls can provide that women cannot? A Study on Real doll by Cathleen Maslen from the University of Western Australia shows that despite the sexual marketing behind the "Real Dolls", their owners do not look at their dolls as sexual objects. Even there had been a case who married his doll in a public ceremony. Some of these Guys take their real dolls too seriously and they have emotional investment and deep attachment with them. There is no doubt that the owners who take their dolls seriously, really love them and that they have a huge emotional investment and attachment with them.

\section{Statement of the problem and research methodology}

Conflict is likely to be experienced whenever ideas, activities, structures and people change in relation to each other. Since the change is not only inevitable but also often desirable, conflict is consequently unavoidable (Francis, 2000). Through an overview to the family structure proposed by Lawrence Stone, one would easily figure out that three major family transformations had happened in the meantime of 300 years from the beginning of sixteenth century to the end of eighteenth century. In the earlier years of this period, our society was structured upon nuclear family, which designated 
living in small houses but being surrounded by other family members, relatives and perhaps people from the community. Apparently the family was not separated from the society. Choosing partner was not a personal choice and usually elder members like grandparents or parents had the privilege to select partners for their children. At that time romance and love was considered as a disorder. There was no secret in the family and the society had the right to know everything happening within the private sphere of the family. As a result, family design was open, dominated and unemotional. Then, later on, the nuclear family was replaced with a limited Patriarchy Family which lasted for two centuries from 16th to the beginning of 18th century. In this new structure of the family, privileging men to be the head of the family and subordinating the women, i.e. diminishing the role of women merely to house works and taking care of children and their husbands and at the same time focusing on love and internal relationship, was increasingly highlighted. The third transformation, however, happened when the power of patriarchy became limited to nuclear family in which individualism emerged and women found their new role in workplace once again and decreased the power of the patriarch (Stone, 1977).

These changes in family structure has initiated new conflicts such as the physical and psychological bonds between guys and dolls. The Real Dolls are designed to recreate and simulate the appearance, texture, and the weight of a female partner. But, despite their primary function of serving as sex partners, there are some more emotional and psychological issues happening between them and men. The owners of these dolls are happy and satisfied by having these dolls as their life companions. Stephen Caroll, for instance, as a user of this doll spelled out, "I do actually enjoy their company. I don't think people truly can appreciate that element" (Joel, 2011). The users of these objects have unanimously confessed that they do love these dolls and they enjoy being with them (BBC). But the question that comes up is, what makes men to be pleased with a doll or with a woman-like-object without head?

The present study aims to find out the reasons behind this conflict: What makes men to be pleased by having relationship with women without head? And what we can do to solve this? In the survey conducted in this study, the video of "Guys and Dolls", BBC Video Documentary, has been shown to 10 people including five male and five female. Then, a questionnaire was given to each one to ask for their opinion based on their gender. By analysing the video and interview of some of the doll-owners, we have found a similar biographical background in these guys' life style. Most of them have experienced a broken relationship which has made them look for a long lasting relationship. They want to be heroes and masters. They have had a deep fear of being rejected. The detailed analyses are in coming parts. Besides that a survey conducted in order to find out the peoples' perspective towards the video clip entitled "Guys and Dolls" which was produced by BBC Documentary in 2007, according to their gender.

\section{Discussion}

\subsection{Power Asymmetry and men's adoption toward it}

The desire of men to have women as their dominator is undeniable. The mission of domination is to establish power asymmetry and it is dependent on that. It is a relationship that most people, in most cultures, most readily associate with the word power (Francis, 2000). The world of power means the world of men which is dominated by men as well. This is a power relation which makes men realize their masculinity by means of practicing it. The power is a main core of economy, politics and society; it plays a significant role in religion, family and the intellectual life.

On individual level, what we assume as masculinity is mixed with men's ability to represent power and control. It implies having power over people and things and the ability to do something or taking the responsibility of doing and acting on behalf of others (Boulding, 1978). It can be seen in the culture of the dominant which had been wide speared for thousands of years, oppressive male/female relationships (Francis, 2000). Patriarchy is a system in which power relations are unequal and men control women's production, reproduction and sexuality.

The mixture of sex and power in oedipal psychology demands men to be bigger and stronger and central oriented in comparison with their partners, mostly in relation with young girls and daughters and not bigger and more powerful mothers (Kaschak, 1992). The feeling of power and the ability to do things on behalf of women makes men feel satisfied. However, since the power distribution within the families and inside societies had recently been changed, men's power has decreased in comparison to past decades and it seems that this fact has become quite challenging and intolerable for some of those men who have not overcome their oedipal complex, yet.

On the other hand, these dolls help men feel satisfied and happy by their being functionally possible to be dressed up in different types of clothing, to change their wigs or makeup, and to have different body temperature. The dolls, therefore, please men's desire of dominating over women. Referring to the BBC Documentary video of guys and dolls, Mike, Gordon and many more of the dolls ' owners enjoy doing shopping or make up for their dolls in their own taste (BBC) Andrew, another doll owner, says that the best part of owning dolls is that they do not complain, they do not get fat, they look good and they enjoy the same TV programs, music and sports that he does (Joel, 2011) Therefore, it is easy to note that these men can fulfil their desire of being powerful and making decision on behalf of women by doing whatever they want with these dolls without any complains or rejection from them.

All the same, unless one appreciates the Freudian concept of Oedipus complex and its subsequent consequences, one would not be able to understand the individual's unconscious impulse towards a displacement of love object and the nature of the power relations existing within his dominant attitude. In his brief analysis of the Freudian concept of Oedipus complex, Pourya and Mehrvand note that according to Freud, in the psychic development of a person there is a process of transition from one phase to the other. He believes that child's sexual life has one significant phase, called a masculine one. During the masculine phase, which Freud calls it the pre-Oedipus phase, the child's love-object is her 
mother. Freud argues that the primary conditions for a choice of objects are the same for all children. Therefore, the little child, initially develops an intense attachment to the mother and a simultaneous hatred for the father as a rival (312).

\subsection{Men `s perspective of women}

The woman's identity is extremely linked with her appearance. A woman's perception of self (which is based in large part on appearance) incorporates the male perspective. From the masculine perspective, women are defined by their bodies. Everything about a woman is both grounded in and defined by her female body and, in particular, its sexuality, defined in masculine society as the ability to arouse, rather than to experience, desire (Kaschak, 1992). Thus man is the one who defines and gives the identity to the women and also this theory shows the perspective of men towards women as they only value the appearance of the women. Quite unexpectedly, the guys in relation with dolls as well as those appearing in the $\mathrm{BBC}$ documentary are very willing to capture photos and video shots with these dolls and frame it as if they are real persons in order to show them to everyone as a proof that they are normal and have even become more successful since they have beautiful women as their life partners.

Sometimes finding partners for some men with low self-esteem is impossible. These dolls, then, function to increase their self-esteem by their appearance, one of the most significant factors from the masculine point of view. Gordon, a doll owner, claims that his two dolls, Ginger and Kelly, do provide him with a boost of self-confident. Addressing the same increase in self-worth, Debra, the Office Manager of Real Dolls, shares, "I've had customers say to me 'You know, I'm 50 years old and I'm losing my hair and I'd never be able to get a real woman that would look like [the dolls]. But the Real Doll can give me that and she will love me no matter what" (Loren, 2011).

The experts on the field, furthermore, declare that problems of the young men in an on-going romantic relationship may also be linked to their poor emotional well-being, because they may be threatening their identity and feelings of selfworth. (Health and Social Behavior, 2011).

\subsection{Men are more emotional and sensitive than women}

Another major reason that has initiated this conflict is the men's fear of being heart-broken and feeling rejected. The common belief that women are more vulnerable when it comes to emotional ups and downs of romantic relationships has been challenged in a study from Wake Forest University. According to the Professor of Sociology, Robin Simon, unhappy romances take a greater emotional toll on the mental health of young men than women, even though men sometimes try to appear tough. Simon maintains that guys just express their distress and vulnerability differently than women. As a proof, the study in which more than 1,000 unmarried young individuals between the ages of 18 and 23 years, came to the conclusion that young women have a harder time dealing with a breakup, but men are the ones who experience more stress and strain during the emotional rollercoaster of relationships.

In other words, while women's mental health is based on their relationship status, single men's mental health is more related to the quality of their romantic relationships. Furthermore, not only men experienced much more stress during rocky relationships, they were also found to get greater emotional and psychological benefits when the relationship is healthy. Researchers claim that these findings contradict the stereotypic image of tough guys who cannot be affected by what happens in their intimate relationships.

Simon, along with a co-author Anne Barrett, associate professor of sociology at Florida State University, suggest a possible explanation for their findings: for young men, their romantic partners are often their primary source of intimacy, while young ladies tend to have more close social ties and are more likely to be closely connected with family and friends (Health and Social Behavior, 2011).

The findings of the study reveal that abusive men were likely to view stressful circumstances as personally threatening, while trying to avoid the situation or repress emotional responses. The in-depth interviews also showed that "violent men are more likely to perceive their partner's behaviour as threatening, regardless of the objective qualities of the behaviour," Williams stated. The situation was even worse for men who tended to avoid or withdraw from conflicts with their partners. Men who felt threatened and who avoided conflict were eight times more likely than others to commit domestic violence (Williams, 2012). Through an evaluation of the behaviour of men towards women and their hidden fear towards losing their partner, the researchers conclude that men are looking for long-lasting relationships with their partners.

In the BBC documentary of the guys and the dolls, we see that these men are looking for long-lasting relationships. Referring to one of these guys who still suffers from the death of his mother and by reviewing the myth of Oedipus as representative of the sexual development of the universal male child and his incestuous desires toward the universal mother, which is indeed a cornerstone of Freudian theory, (Kaschak, 1992), one would easily conclude that men are afraid of losing their partners. And this issue proves that men are more emotional than women.

\subsection{Stereotyping of masculinity and feminists}

Another factor to be taken into consideration is that society trains boys not to expose their emotions, particularly the moments of their crying, and hence not to reveal their vulnerability. In fact, researchers have noted that the only formally approved emotion for men to express publicly is proved to be anger. Perhaps, that is why it is not a surprise that men drown their sadness, vulnerability and emotional pain in alcohol and sometimes even drugs and human replacement objects as dolls (Simon and Barret) 
The media and society ideologically display and dictate men to be powerful, supportive and tough even though some may not be so. Nowadays, within this new structure of the families women also do not accept men's domination. Some men say that they are not powerful and muscular enough that the media propagates and makes them to strive for. And from stereotypical point of view and considering the politics of media, if one does not have enough power, one will definitely be not considered as a qualified masculine. These controversies sometimes make men prefer having dolls as their life partners, for acting as a hero for a doll is much easier than being one for a real person. Furthermore, the dolls would not have the chance of rejecting their male companions.

Violence, the harmful and destructive exercise of power over others, is both the means and the outcome of domination. A culture of domination is a culture of violence. In the words of Johan Galtung, "cultural violence makes direct and structural violence look, even feel, right - or at least not wrong" (Galtung, 1990: p291). Therefore, having a doll, being its master as well as its hero seems to be one significant solution to satisfy the desire of men or the desire that the society might want from them.

Another key issue is a common worry that men generally encounter in their sexual relationships. In this regard, Gorden, a user of one of the dolls, has stated, "I'd say for me the sex with real dolls is better because in the back of my mind when I'm having sex with a real woman, it's like 'damn I hope I don't get her pregnant' or 'I hope she does not have any disease" (22). After all, it's true that sex with dolls offers limited opportunities for contracting sexually transmitted diseases, but as Loren has confirmed, their rubber vaginas do require regular cleaning to prevent the festering of bacteria (29). This key issue also reflects the fact that that these men are not able to take the responsibility of their own action.

\section{Conclusion}

The results show that women can hardly accept the fact of using dolls as replacement to real partners in comparison with men. For four of these women, this issue was unbelievable and not logical and only one of them claimed that she respects the choice. On the contrary, for men, the results were different. Despite two of them who rejected the idea and considered it as an illogical deed, two of them claimed that they can understand the situation yet in turn it would also imply men's weakness. One of the male participants also believed that this issue can be acceptable since these guys are happy with the dolls and they need a relationship so they do have it now. Both parts' assumption is, the need of men to have power leads them to want to have relationship with dolls since they cannot achieve it, in their willing in real life.

From a psychoanalytic point of view, no one is able to fully resolve the oedipal complex incorporated in the unconscious of the individual from the very stages of early childhood. In addition, the civilization and the culture in which the individuals live not only does not demand or require its resolution but it also, on the contrary, rewards and perpetuates it. If men are called upon to resolve the issue, it is merely through women, who have taken the lead in this phase of psychological-cultural development. For a man in the oedipal phase of development to allow a woman, or women collectively, the prerogative of taking this initiative is not a psychologically simple task. Even if the masculine is intellectually able to comprehend and realize that women are treated unfairly, he must cut off access to his own unresolved oedipal conflicts, access to which would thrust him into the experience of his own relative powerlessness, his own mortality, in sum, his own mundane humanity. He turns into an object of being, no more and no less than a woman. The male subject would be compelled to see for himself, to discontinue placing women between himself and his own experience of himself (Kascha, 43).

Breaking the stereotypes of men should be dominating and aggressive and women should be caring, loving and submissive. These stereotypes of masculinity and femininity are not only social constructs but also have been internalized by both men and women. While the pressure to earn and look after the family is more on the man, the women are supposed to do the menial jobs and take care of their children and even other members of the family. It is because of these gender stereotypes that women are at a disadvantage and are vulnerable to violence and other kinds of discriminations and injustice (Ray, 71). Laws of Manu insist that since women are disloyal by their very nature, they must be made dependent on men. The husband should be constantly worshiped as a god, which symbolized that man is a lord, master, owner, or provider and women were the subordinates. It legitimized that a woman should never be made independent, as a daughter, she should be under the surveillance of her father, as a wife, of her husband and as a widow, of her son (Chakravarti, 2006: 75).

All these stereotypes empower men to demand for the worship and subordination of women, but the society has dramatically transformed in recent decades and the need for an eradication or alteration of these stereotypes to suit the new design of relationship has been highlighted. The belief of "Civilized Man says: I am Self, I am Master, all the rest is other - outside, below, underneath, subservient. I own, I use, I explore, I exploit, I control. What I do is what matters? What I want is what matter is for. I am that I am, and the resits women and wilderness, to be used as I see fit" should be altered in the mind-set of men for their acceptance of women as the people who have the right to refuse them and say no or make a choice (Zerzan, 43).

\section{References}

Abele, S., \& Holt, N. (2007). Guys and Dolls [Documentary]. Available from the British Broadcasting Corporation, Broadcasting House. United Kingdom: Portland Place London W1A 1AA. 
Francis, D. (2004). Culture, power asymmetries and gender in conflict transformation in Transforming Ethnopolitical Conflict: The Berghof Handbook (pp. 91-107). Berline, Germany: VS Verlag für Sozialwissenschaften.

Kaschak, E. (1993). Engendered Lives. A New Psychology of Women's Experiences. NY, United States: Basic Books.

Lane, Michael. (1999). Real Doll. Monk Magazine, Retrieved from http://www.monk.com/display.php?p=People\&id=38

Loren, A. (2011). Yes, There Are Men That Date Life-Size Dolls. Clutch Magazine. Retrieved from http://www.clutchmagonline.com/2011/08/yes-there-are-men-that-date-life-size-dolls

MAN, M. K. (1994). Men, Feminism, and Men's Contradictory Experiences of Power. In Theorizing masculinities. (pp. 142-165). NY, United States: SAGE Publications.

Pourya Asl \& Ahad Mehrvand. (2014). Unwelcomed Civilization: Emily Brontë's Symbolic Anti-Patriarchy in Wuthering Heights. International Journal of Comparative Literature \& Translation Studies. Australian International Academic Centre, 2(2).

Ray, Surayita. (2000). Understanding Patriarchy. Political Science Department, University of New Delhi, pp. 1-21.

Scott, Lisa. (2006,). Flexible Friendship. Metro News, Retrieved from http://metro.co.uk/2006/02/22/flexiblefriendship-21056.

Stone, L. (1979). The family sex and marriage: in England 1500-1800. New York, United States: Harper and Row.

Whelan, J. (2011). Silicone love: Guys and Dolls. ABC News. Retrieved from http://www.abc.net.au/news/2011-0721/australian-men-living-with-realdolls/2802302

Zeran, J. (2004). Patriarchy, Civilization, And The Origins Of Gender. Retrieved from http://theanarchistlibrary.org/library/john-zerzan-patriarchy-civilization-and-the-origins-of-gender 